\title{
Completion thyroidectomy of well-differentiated thyroid cancer - a prospective, miserandomised study
}

\author{
Wtórnie całkowite zabiegi usunięcia resztkowego gruczołu tarczowego \\ w dobrze zróżnicowanych rakach tarczycy — badanie prospektywne, \\ randomizowane
}

\author{
Monika Proczko', Tomasz Stefaniak', Krzysztof Sworczak², Jarosław Kobiela ${ }^{1}$, Andrzej Jacek Łachiński ${ }^{1}$, \\ Pieter Stepaniak', Zbigniew Śledziński ${ }^{1}$
}

${ }^{1}$ Department of General, Endocrine and Transplant Surgery, Medical University of Gdansk, Poland

${ }^{2}$ Department of Endocrinology and Internal Medicine, Medical University of Gdansk, Poland

\begin{abstract}
Introduction: Postoperatively diagnosed papillary or follicular thyroid cancer in subtotally thyroidectomised patients requires a completion thyroidectomy. Re-operation with a gamma probe can be particularly useful in these patients.

The aim of this study was to evaluate the benefits of using an intraoperative hand-held gamma detector during completion thyroidectomy in patients with well-differentiated thyroid cancer (WTC).

Material and methods: 75 patients with WTC qualified for total re-thyroidectomy. In 43 patients, Group I (Nav), a hand-held gamma probe (Navigator GPS) was used intraoperatively. 32 patients were re-operated without the gamma probe (Group II). In Group I, thyroid remnants were removed based on counted gamma signals. To estimate the radicality of reoperation in both groups, thyroglobulin (Tg) levels were determined and total body scanning (TBS) - $\mathrm{I}^{131}$ uptake — was performed.

Results: Total thyroidectomy with central lymphadenectomy was performed in 75 cases. The average level of Tg and iodine uptake after radicalisation was lower in Group I (Nav) than in Group II (3.32 \pm 2.09 v. $4.58 \pm 2.5 \mathrm{ng} / \mathrm{mL}$, respectively, for Tg [p $=0.021]$ and $6.29 \pm$ 3.38 v. $7.31 \pm 2.29 \mathrm{ng} / \mathrm{mL}$, respectively, for iodine uptake $[\mathrm{p}=0.187])$. Additionally, the frequency of postoperative complications was comparable, the difference in both groups was not significant, despite the use of the gamma probe $(\mathrm{p}=0.109)$.

Conclusions: The intraoperative use of a hand-held gamma detector can help to improve the radicality of a completion thyroidectomy procedure after an incomplete primary thyroid resection, but the results of this procedure in the hands of an experienced surgeon are comparable whether or not the gamma detector is used. (Endokrynol Pol 2013; 64 (5): 335-339)
\end{abstract}

Key words: well-differentiated thyroid cancer, completion thyroidectomy, gamma probe, iodoradiotherapy

\section{Streszczenie}

Wstęp: Rozpoznanie po operacjach pierwotnie niedoszczętnych raka brodawkowatego lub pęcherzykowego tarczycy wymaga radykalizacji leczenia operacyjnego i usunięcia całego gruczołu tarczowego. W zmienionych przez tkankę bliznowatą warunkach anatomicznych radykalność tych zabiegów może być niezadowalająca i w konsekwencji wpływać na wyniki tarapii.

Celem pracy była ocena korzyści wynikających z zastosowania ręcznego gamma nawigatora w zabiegach wtórnie całkowitych w przypadkach dobrze zróżnicowanych raków tarczycy.

Material i metody: W pracy przedstawiono 75 przypadków chorych z dobrze zróżnicowanymi rakami tarczycy, zakwalifikowanych do radykalizacji leczenia operacyjnego. W 43 przypadkach (grupa I) śródoperacyjnie zastosowano ręczny gamma nawigator (Navigator GPS), 32 chorych reoperowano bez użycia wyżej wymienionego urządzenia (grupa II). W celu oceny radykalności wtórnie całkowitego zabiegu w obu grupach chorych badano pooperacyjnie stężenie tyreoglobuliny (Tg) oraz oceniano wyniki badania scyntygrafii całego ciała $\left(\mathrm{I}^{131}\right)$ - jodochwytność. W obu grupach porównano również wystąpienie powikłań po zabiegach wtórnie radykalnych.

Wyniki: Podczas radykalizacji we wszystkich przypadkach wykonano całkowite wycięcie gruczołu tarczowego wraz z wycięciem węzłów chłonnych przedziału centralnego. Pooperacyjne średnie stęzenie Tg oraz jodochwytność były niższe w grupie I w porównaniu z grupą II: $(3,32 \pm 2,09$ v. $4,58 \pm 2,5 \mathrm{ng} / \mathrm{ml}$, [p = 0,021] jodochwytność: 6,9 $\pm 3,38$ (grupa I) v. 7,31 $\pm 2,29 \mathrm{ng} / \mathrm{ml}$ (grupa II) [p = 0,187]). Użycie nawigatora nie miało wpływu na częstość wystąpienia pooperacyjnych powikłań $w$ obu grupach chorych $(\mathrm{p}=0,109)$.

Wnioski: Śródoperacyjne zastosowanie nawigatora może być pomocne w osiągnięciu lepszej radykalności pierwotnie nieradykalnych operacji, chociaż obserwowane wyniki pozwalają na stwierdzenie, że zabieg ten wykonywany przez doświadczonego operatora pozwala na osiągnięcie porównywalnej radykalności niezależnie od śródoperacyjnej detekcji izotopowej. (Endokrynol Pol 2013; 64 (5): 335-339)

Słowa kluczowe: dobrze zróżnicowane raki tarczycy, zabiegi wtórnie całkowite, gamma nawigator, jodoradioterapia 


\section{Introduction}

The treatment of thyroid cancer is a multilevel and interdisciplinary process involving not only the surgical procedure, but also isotope $\mathrm{I}^{131}$ therapy, hormone therapy, radiotherapy, and, in rare cases, chemotherapy. Specific guidelines have been prescribed by surgical and thyreological associations (e.g. the American Thyroid Association or Deutsche Gesselschaft für Chirurgie); according to them, the recommended treatment is a total extracapsular thyroidectomy with removal of lymph nodes of the central neck compartment and of the upper mediastinum (groups VI and VII) and total thyroidectomy is defined as a gland resection after which the remaining thyroid parenchyma is less than $1 \mathrm{ml}$ on each side [1-3].

After anything less than radical treatment, there is a recommendation to perform the second surgery that involves total removal of the thyroid. A radical operation with intraoperative radioisotopic examination is considered when iodine uptake after 24 hours does not exceed 1\% [4-6]. Unfortunately, there is a group of patients in whom, after a macroscopically-radical operation, the postoperative scintiscanning performed one month after surgery shows the presence of remnant thyroid tissue [7-9] or due to difficulties in preoperative diagnosis of thyroid cancer, primary radical treatment was not considered to be needed. In such cases, it is necessary to perform a secondary radical operation. The completeness of these types of operations is often doubtful and there is a higher risk of postoperative complications [10, 11]. According to the literature, the use of intraoperative scintiscanning (via a gamma detector) can improve the radicality of the secondary operation and thus should increase the percentage of long-term survivors [11, 12].

The aims of the study were:

- To assess the usefulness of an intraoperative gamma detector in patients requiring a completion thyroidectomy

- To analyse the presence of cancer in thyroid remnants in patients after the original non-radical surgery

\section{Material and methods}

Seventy-five patients underwent re-operation between 2006 and 2011 because of a diagnosis of WTC (well-differentiated thyroid cancer) in the final histopathological examination. Of these, 43 patients were operated on with the assistance of an intraoperative gamma detector (Navigator GPS [Gamma Positioning System, Tyco Healthcare Group, USA]): this group we call Group I (Nav). The 32 remaining patients were re-operated on using standard surgical technique without the use of a gamma detector: this group we call Group II. Patients were randomly assigned to either Group I (Nav) or II.

All 75 analysed patients were originally operated on because of a nodular goitre and initially underwent a subtotal thyroidectomy. In all cases, histopathological examination revealed WTC. In Group I (Nav), the histopathological examination revealed PTC in 30 patients and FTC in 13 patients, whereas in Group II such an examination revealed PTC in 26 patients and FTC in six patients ( $\mathrm{p}=\mathrm{ns}$; $\mathrm{Chi}^{2}$ test).

Due to the size of the cancer focus $(\geq 1 \mathrm{~cm})$ or the multifocal presentation, all patients were qualified for secondary surgical treatment within 2-3 months of the primary treatment.

Primary tumours were staged according to the Union for International Cancer Control (UJCC) pTNM classification. In Group I (Nav), there were 11 patients of stage $\mathrm{T}_{1}(26 \%), 30$ of $\mathrm{T}_{2}(70 \%)$, one of $\mathrm{T}_{3}(2 \%)$ and one of $\mathrm{T}_{4}(2 \%)$ classification. In Group II there were seven patients of stage $\mathrm{T}_{1}(22 \%)$ and stage $\mathrm{T}_{2}(78 \%)$ classification ( $\mathrm{p}=\mathrm{ns}$; U-Mann-Whitney test).

In Group I (Nav), 1-2 mCi of $\mathrm{I}^{131}$ was administrated orally one day before surgery. An intraoperative gamma detector was used with a $10-\mathrm{mm}$ scintillation probe. This detector is a portable, battery-operated device used for the detection of gamma radiation photons generated during radio decay. It enables the identification and quantitative assessment of gamma radiation from isotopes localised inside the body and its tissues. Therefore, it is a non-imaging technique that involves the counting of radionuclides absorbed by individual organs. Obtained counts are based on the comparative measurement of radiopharmaceutical uptake in two or more areas of interest. During the secondary radical procedures, the radioactivity was counted in the neck and background/reference radioactivity was counted in the left shoulder. High counts indicated the presence of accumulating tissue $\mathrm{I}^{131}$. Thyroid tissue remnants were excised according to the scintillation counts. The probe was also used for the detection of individual lymph nodes and groups of lymph nodes before and after the excision. Collected specimens were then sent for histopathological verification.

In our study, a low dose 1-2 mCi of $\mathrm{I}^{131}$ was used during the intraoperative procedure and the count time length from the residual thyroid tissue was ten seconds. Administration of such a small dose of $\mathrm{I}^{131}$ allows for its rapid elimination and does not impair the scintigraphy (TBS) performed six weeks after surgery. For the first 24 hours, $90 \%$ of the non-accumulated dose is excreted, followed by $5 \%$ on the second and third days. Accumulation of radioiodine in the thyroid gland can be detected within ten half-lives, but after 
five weeks it usually remains at less than $1 \%$ of the administered dose.

All of the re-thyroidectomy cases were performed by one surgical team well-experienced in thyroid surgery. Early result evaluation involved the presence of postoperative complications specific to thyroid surgery: paresis or palsy of the laryngeal nerve and hypocalcaemia.

The radicality of the second surgery was assessed by a radioiodine uptake test of the neck and by TBS performed 4-8 weeks after surgery under the condition of endogenous TSH stimulation. Dispersed radioiodine accumulation was considered not significant when it was less than $1 \%$. Thyroglobulin (Tg) levels in the serum were also compared to estimate the radicality of completion thyroidectomy in both groups.

The study was approved by the Local Ethical Committee at the Medical University of Gdańsk. Patients signed informed consent forms and were blinded to the result of the randomisation. Patients from Group II received a placebo pill on the preoperative day and were treated under the same safety regimen as patients from Group I (Nav). Early results and complications were evaluated by members of the team blinded to the result of the randomisation. The evaluators of the long-term results (radioiodine uptake test and Tg level) were also blinded to the result of the randomisation. Statistical analysis was conducted using STATISTICA 9.0 PL software licensed to the Medical University of Gdansk and included use of the Student t-test, $\mathrm{Chi}^{2}$ test. A p value $<0.05$ was considered as a statistically significant. The conducted study was prospective and randomised.

\section{Results}

In both groups, excision of thyroid tissue remnants and central (compartments VI and VII) lymphadenectomy was performed in all patients.

Analysis of pooled complications (postoperative hypocalcaemia and paralysis or palsy of the laryngeal nerve) revealed a comparable number of these complications in Group I (Nav) versus Group II: there was no statistically significant difference $(\mathrm{p}=0.109)$. Also analysis of postoperative hypocalcaemia did not reveal a statistically significant difference in total calcium levels between these two groups ( $\mathrm{p}=0.526)$

Average values of Tg after radicalisation in Group I (Nav) were $3.32 \pm 2.09 \mathrm{ng} / \mathrm{mL}$ and in Group II were 4.58 $\pm 2.5 \mathrm{ng} / \mathrm{mL}(\mathrm{p}=0.021)$. The reference Tg value, based on normal physiological conditions, should not exceed $52 \mathrm{ng} / \mathrm{mL}$ (79 pmol/U), and after total thyroidectomy the level of $\mathrm{Tg}$ is close to or equals $0 \mathrm{ng} / \mathrm{mL}$ (Fig. 1).

In the control TBS performed 4-8 weeks after surgical radicalisation, the difference in average $\mathrm{J}^{131}$ uptake in

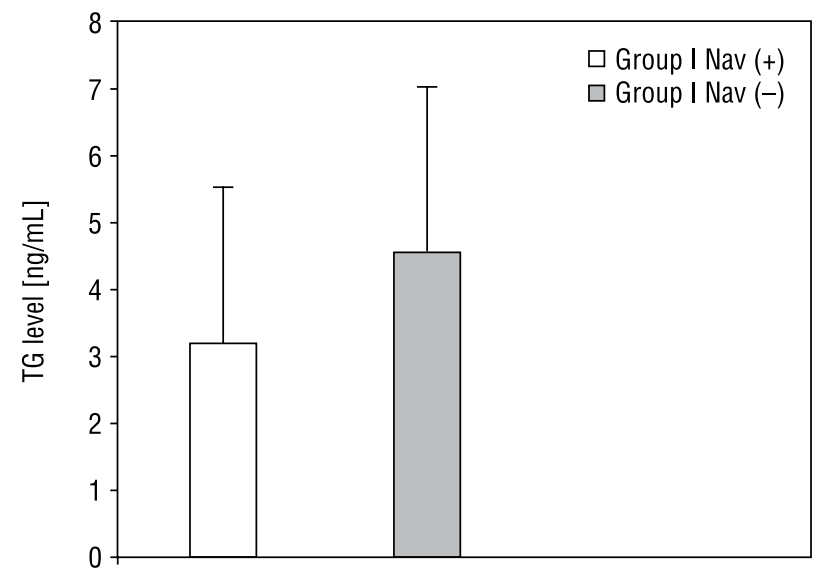

Figure 1. Results of completion thyroidectomy: Tg level, $t$-Student test, $p=0.021$

Rycina 1. Wyniki radykalizacji usunięcia tarczycy: stężenie tyreoglobuliny po zabiegach z wykorzystaniem lub bez wykorzystania GPS Navigatora. Analiza testem $t$-Studenta $p=0,021$

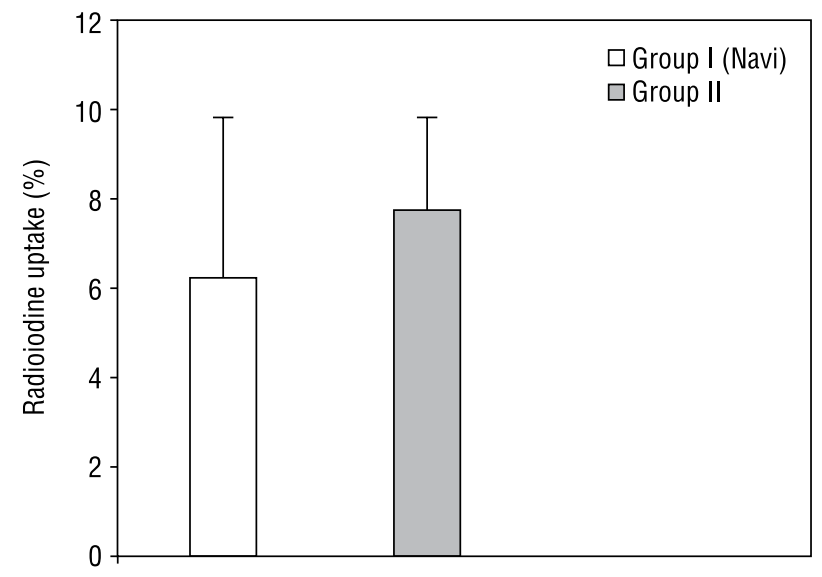

Figure 2. Results of completion thyroidectomy: radioiodine uptake, t-Student test, $p=0.1875$

Rycina 2. Wyniki radykalizacji usunięcia tarczycy: stopień jodochwytności po zabiegach z wykorzystaniem lub bez wykorzystania GPS Navigatora. Analiza testem $t$-Studenta $p=0,1875$

Group I versus Group II was not statistically significant $(6.29 \pm 3.38 \%$ v. $7.31 \pm 2.29 \%$, respectively; $\mathrm{p}=0.187)$ (Fig. 2).

In our analysed group of 75 patients, histopathological examination detected malignancy in $10 \%$ of thyroid remnants in Group I (Nav) (PTC in three patients [6\%] and FTC in one patient [3\%]). In the remaining 39 patients $(91 \%)$, normal thyroid gland tissue was found. In Group II, malignancy was detected in $21 \%$ of excised remnants (all seven cases of PTC), while normal thyroid gland tissue was confirmed in the remaining 25 cases (79\%) (Fig. 3). 


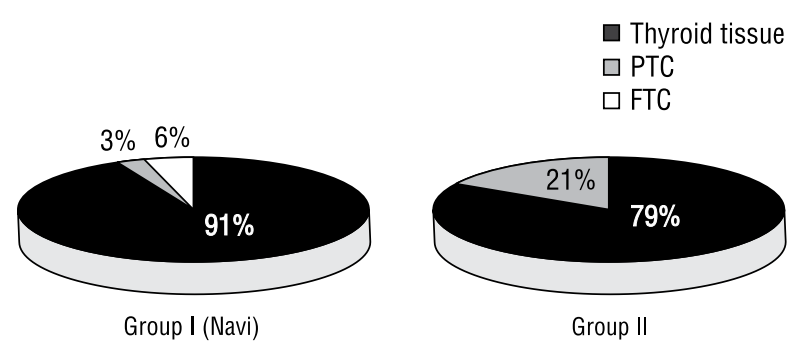

Figure 3. Histopathological results after completion thyroidectomy in Groups I (Navi) and II, Ch ${ }^{2}$ with Fisher correction $p>0.500$

Rycina 3. Wynik histopatologiczny z materiału usuniętego w trakcie zabiegu wtórnego w grupach I (Navi), II. Analiza testem $C h i^{2} z$ poprawka Fishera $p>0.500$

\section{Discussion}

Subtotally thyroidectomised patients finally diagnosed with WTC should undergo completion thyroidectomy [3]. Findings of possible remaining cancer foci in the thyroid remnants support this approach [13-15]. Moreover, this statement allows also for better postoperative monitoring and even makes adjuvant $\mathrm{I}^{131}$ unnecessary $[9,10,13,16]$. Unfortunately, the total remnants removal in scar tissue is technically difficult. Identification and precise localisation of the residual thyroid tissue and the evaluation of the completeness of resection are problematic. Re-thyroidectomies are also associated with a higher risk of postoperative complications [17-19].

Opponents of completion thyroidectomy argue that long-term results of WTC treatment are satisfactory, and that the survival rate does not increase in totally thyroidectomised patients. Rossi et al., Cady et al., Simpson et al., and Grant et al. argue that radicalisation only carries unnecessary complications [9, 20-22].

The timing of completion thyroidectomy is of the highest importance: the best time is within five days of the first operation or 2-3 months later [18,19]. Patients from the analysed groups were re-operated within 8-16 weeks (mean: 11 weeks).

The usefulness of an intraoperative gamma probe is not unanimously agreed. Doubts result from differences of physical properties and methodology including the type of isotope used, timing of measurement, and the type of device used. The issue has been raised that if radio decay is a random phenomenon, the counts made in a short period of time may not be representative and thus false-positive results may be obtained [23-25]. In our study it was based on counts obtained with the probe held stationary in a similar position on each of the measured areas and on a comparison of the counts obtained from each area.

Iodine uptake by thyroid tissue remnants is normally low, and that of cancer tissues is almost undetectable. According to the literature, the thyroid gland captures
$1-1.75 \%$ of $\mathrm{I}^{131}$ per gram of thyroid tissue. In cases of WTC, the uptake is lower than $0.5 \%$ per gram $[23,26,27]$. This may result in limited effectiveness of adjuvant radioiodine therapy and further legitimates the radical approach both in the primary and secondary surgical treatment.

Removing the entire thyroid gland seems to be an essential element of therapy. It makes the blood serum $\mathrm{Tg}$ concentration a sensitive and specific marker of the radicality of the surgical treatment and potential cancer recurrence $[15,16]$. A Tg level below $2 \mathrm{ng} / \mathrm{mL}$ is considered undetectable and is associated with a virtual lack of thyroid tissue. In Group I (Nav), the Tg level was lower than $2 \mathrm{ng} / \mathrm{mL}$ in 28 patients (65\%), and 2-8 ng/ $/ \mathrm{mL}$ in the remaining 15 patients. The overall Group I mean Tg level was $3.32 \pm 2.09 \mathrm{ng} / \mathrm{mL}$, compared to the reference value in normal euthyroid patients of up to $40 \mathrm{ng} / \mathrm{mL}$, the mean Tg level in Group II was $4.58 \pm$ $\pm 2.5 \mathrm{ng} / \mathrm{mL}$. The difference between Group I (Nav) and Group II was statistically significant $(\mathrm{p}=0.021)$.

These results are evidence that better radicality is achieved during secondary treatment if an intraoperative gamma detector is used. [28-30]. Ablation therapy is not at all necessary when iodine uptake after 24 hours (T24 h) is less than 1-3\% [25-28]. Iodine uptake $>1 \% / 3 \%$ is an indication for adjuvant radioiodotherapy. Achieving a control result of iodine uptake at $\mathrm{T} 24 \mathrm{~h}<1 \%$ is difficult or simply impossible even in the best surgical centres [30].

According to the European Association of Nuclear Medicine (EANM), ablative treatment $\mathrm{I}^{131}$ should be provided in all cases of WTC, even in cases of microcancer if: (i) there is a history of ionising radiation; (ii) it is a diffuse sclerosing variant of PTC; or (iii) thyroid capsule infiltration is observed on histopathological examination. The statement of the European Thyroid Association (ETA) is more liberal and recommends ablative treatment after total thyroidectomy only in T3-4 stages of primary tumour or in cases of metastases to lymph nodes (N1). Experience in Poland suggests $\mathrm{I}^{131}$ therapy also for $\mathrm{pT}_{1 \mathrm{~b}}-\mathrm{T}_{2}, \mathrm{~N}_{0}, \mathrm{M}_{0}$ cases [26, 33].

In our study, scintigraphy of the whole body was carried out with the evaluation of iodine uptake in both groups of patients at six weeks after the completion surgery. In Group I, average iodine uptake was $6.29 \pm 3.38 \%$, whereas in Group II, iodine uptake was $7.31 \pm 2.29 \%$ $(p=0.187)$. According to standard recommendations in Poland, 51 (68\%) patients from both examined groups were qualified to the ablative treatment with $\mathrm{I}^{131}$.

Another important issue supporting the radical approach to re-thyroidectomy is highlighted by the reports of malignant lesions found in remnants that were removed during the second surgery. Levin et al. detected cancer foci in remaining tissue in $22 \%$ of re-operated patients [34]. In our analysed group of 
75 patients, histopathological examination detected malignancy in 9\% of thyroid remnants in Group I (Nav). In Group II, malignancy was detected in $21 \%$ of excised remnants (all PTC), while normal thyroid gland tissue was confirmed in the remaining 25 cases (79\%).

There is no question that completion thyroidectomy is most beneficial in cases with multifocal cancer presentation. According to the literature, the risk of recurrence in the contralateral lobe is $5-24 \%$ [4, 13-15]. Among the ten patients $(26 \%)$ from both analysed groups, in whom foci of WTC were detected in thyroid remnants, there were also two cases in whom malignancy was revealed in the stump of the contralateral lobe.

The percentage of thyroid surgery complications is higher in patients operated primarily for thyroid cancer; laryngeal nerve damage is observed in 3.3-6.4\% and hypocalcaemia in $1.6-5.4 \%$ of patients. These rates are increased in secondary operations, $3.0-10.8 \%$ for laryngeal nerve injury and hypocalcaemia up to $30-50 \%$ [17-19, 24, 34].

In our study, we observed in three patients (6.97\%) a transient paresis of laryngeal nerve, and permanent palsy in one case $(2.3 \%)$. Also the frequency of postoperative hypocalcaemia did not differ significantly between the two groups in our study. This phenomenon is normally observed in as much as $50 \%$ of thyroidectomies, and in more than $14 \%$ of cases it is permanent [35-37].

\section{Conclusion}

Completion thyroidectomy with the use of an intraoperative gamma detector can allow for better radicality of the surgical procedure. This enables the detection of the thyroid tissue with potential cancer foci, which are not macroscopically identifiable otherwise among scar tissue. On the other hand, a completion thyroidectomy procedure carried out by an experienced surgeon can be both radical and safe enough even without using a gamma hand probe.

\section{References}

1. AACE/AME. Task Force on Thyroid Nodules American Association of Clinical Endocrinologists and Associazione Medici Endocrinologi medical guidelines for clinical practice for the diagnosis and management of thyroid nodules. Endocr Pract 2006; 12: 63-102.

2. Elaraj DM, Clark OH. Changing management in patients with papillary thyroid cancer. Curr Treat Options Oncol 2007; 8: 305-13.

3. Expert Review of Anticancer Therapy. Current Issues in Cancer of the head and neck J Nucl Med Technol 2010; 10: 1429-1437.

4. Urken ML. Prognosis and management of invasive well-differentiated thyroid cancer. Otolaryngol Clin North Am 2010; 43: 301-328.

5. Kebebew E, Clark OH. Differentiated thyroid cancer: "complete" rational approach. World J Surg 2000; 24: 942-951.

6. Tsang RW, Brierley JD, Simpson WJ et al. The effect of surgery, radioiodine and external radiation therapy on clinic outcome of patients with differentiated thyroid carcinoma. Cancer 1998; 82: 3235-3240.

7. Dackiew AP, Zwinger M. Extent of Surgery for differentiated thyroid cancer. Surg. Clin. of N Am 2004; 84: 817-832.

8. Ito Y, Higashiyama T, Takamura Yet al. Clinical outcomes of patients with papillary thyroid carcinoma after the detection of distant recurrence. World J Surg 2010; 34: 2333-2337.
9. Grant CG, Hay ID, Gough IR et al. Local reccurance in papillary thyroid cancinoma: is exent of surgical resection important? Surgery 1988; 104: 954-962.

10. Bernet V. Approach to the patient with incidental papillary microcarcinoma. J Clin Endocrinol Metab 2010; 95: 3586-3592.

11. Simon D, Goretzki PE, Witte J et al. Incidence of regional reccurance giuding radicality in differentiated thyroid carcinoma. World J Surg 1996; 20: 860-866.

12. Scheumann GF, Seelinger H, Musholt TJ et al. Completion thyroidectomy in 131 patients with differentiated thyroid carcinoma Eur J Surg 1996; 162: 677-684.

13. Gallowitch HJ, Mikosch P, Kresnik E et al. Lymphoscintigraphy and gamma probe-guided surgery in papillary thyroid carcinoma. The setine node concept in thyroid carcinoma. Clin Nucl Med 1999; 24: 744-746.

14. Clark HO. Endocrine surgery of thyroid and parathyroid glands. The C V Mosby Company. St. Louis, Torronto, Princeton 1985.

15. Asanuma K, Kobayashi S, Sugenoya A et al. Clinical recurrence of papillary thyroid cancer in the remnant lobe. Eur J Surg 2000; 166: 202-206.

16. Mazzaferri EL, Robbins RJ, Spencer CA et al. A consensus report of the role of serum thyroglobulin as a monitoring method for low risk patients with papillary thyroid carcinoma J Clin Endocrinol Metab 2003; 88: 1433-41.

17. Cheach WK, Arci C, Ituarte PHG et al. Complications of neck dissection for thyroid cancer. World J Surg 2002; 26: 1013-1016.

18. Erdem E, Gülçelik MA, Kuru B et al Comparison of completion thyroidectomy and primary surgery for differentiated thyroid carcinoma. EJSO 2003; 29: 747-749.

19. Kupferman ME, Mandel SJ, Di Donato L. Safety of completion thyroidectomy following unilateral lobectomy for well-differentiated thyroid cancer. Laryngoscope 2002; 112: 1209-1212.

20. Cady B., Rossi R. An expanded view of risk group definition in differentiated thyroid carcinoma. Surgery 1988; 104: 947-953.

21. Gimm O, Brauckhoff $M$, Thanh PN et al. An update on thyroid surgery. Eur J Nucl Med 2002; 29: 447-452.

22. Hay ID, Grant CS, Taylor WF et al. Ipsilateral lobectomy versus bilatera lobar resection in papillary thyroid carcinoma: a retrospective analysis of surgical outcome using a novel prognostic scoring system. Surgery 1987; 102: 1088-1095.

23. Hänscheid $\mathrm{H}$, Lassmann $\mathrm{M}$, Luster $\mathrm{M}$ et al. Iodine biokinetics and dosimetry in radioiodine therapy of thyroid cancer: procedures and results of a prospective international controlled study of ablation after rhTSH or hormone withdrawal. J Nucl Med 2006; 47: 648-654.

24. Erbie Y, Barabaros U, Deveci U et al. Gamma probe-guided surgery for revision thyroidectomy: in comparison with conventional technique. J Endocrinol Incest 2005; 28: 583-588.

25. Luster M, Clarke SE, Dietlein M et al. Guidelines for radioiodine therapy of differentiated thyroid cancer. EurJ Nucl Med Mol Imaging 2008; 35: 1941-1959.

26. Kukulska A, Krajewska J, Gawkowska-Suwińska M et al. Radioiodine thyroid remnant ablation in patients with differentiated thyroid carcinoma (DTC): prospective comparison of long-term outcomes of treatment with 30,60 and $100 \mathrm{mCi}$. Thyroid Res 2010; 3: 9

27. Travagli JP, Cailleux F, Ricard M et al. Combination of Radioiodine ( $\left({ }^{131}\right)$ and Probe-guided Surgery for Persistent or recurrent Thyroid Carcinoma. J Clin Endocrinol Metab 1998; 83: 2675-2680.

28. Salvatori M, Rufini V, Reale F et al. Radio-guided Surgery for Lymph Node Recurrences of Differentiated Thyroid Cancer. World J Surg 2003; 10: 7014-7018.

29. Leblanc $G$, Tabah R, Liberman $M$ et al. Large remnant ${ }^{131} I$ ablation as an alternative to completion/total thyroidectomy in the treatment of welldifferentiated thyroid cancer, Surgery 2004; 136: 1275-1280.

30. Rubello D, Salvatori M, Pelizzo MR et al. Radio-guided surgery of differentiated thyroid cancer using $\mathrm{J}^{131}$ or ${ }^{99 \mathrm{~m}} \mathrm{Tc}-\mathrm{Sestamibi}$. Nucl. Med Commun 2006; 27: 1-4.

31. Negele T, Meisetschläger G, Bruckner T et al. Radio-guided surgery for persistent differentiated papillary thyroid cancer: case presentations and review of the literature. Langenbecks Arch Surg 2006; 391: 178-186.

32. Sawka AM, Thephamongkhol K, Brouwers M et al. Clinical review 170 A systematic review and metaanalysis of the effectiveness of radioactive iodine remnant ablation for well-differentiated thyroid cancer. Clin Endocrinol Metab 2004; 89: 3668-3676.

33. Rekomendacje "Diagnostyka i leczenie raka tarczycy" przyjęte podczas III Konferencji Naukowej "Rak tarczycy” Szczyrk 2006. Endokrynol Po 2006; 57: 458-477.

34. Levin KE, Clark OH, Duh QJ et al. Reoperative thyroid surgery. Surgery 1992; 111: 604-609.

35. Pisanu A, Piu S, Cois A et al. Hypocalcemia following total thyroidectomy: early factors predicting long-term outcome. G Chir 2005; 26: 131-134.

36. Proczko-Markuszewska M, Kobiela J, Stefaniak T et al. Postoperative PTH measurement as a predictor of hypocalcaemia after thyroidectomy. Acta Chir Belg 2010; 110: 40-44.

37. Thomusch O, Machens A, Sekulla $\mathrm{C}$ et al. The impact of surgical technique on postoperative hypoparathyroidism in bilateral thyroid surgery: a multivariate analysis of 5846 consecutive patients. Surgery 2003; 133: 180-185. 